\title{
Melanthera discoidea: UM NOVO HOSPEDEIRO DE Ralstonia solanacearum
}

\section{ROSALEE A. COELHO NETTO ${ }^{1}$, HIROSHI NODA ${ }^{1} \&$ BERNARD BOHER $^{2}$}

Instituto Nacional de Pesquisa da Amazônia, Coordenação de Pesquisa em Ciências Agronômicas, Cx. Postal 478, CEP 69011-670, Manaus, AM, e-mail: rcoelho@inpa.gov.br; Institut de Recherche pour le Développement, 213 Rue La Fayette, F-75480, Paris, França

(Aceito para publicação em 21/08/2001)

Autor para correspondência: Rosalee A. Coelho Netto

\section{ABSTRACT \\ Melanthera discoidea: a new Ralstonia solanacearum host}

Melanthera discoidea, a member of the Asteraceae family, is a common weed in vegetable production areas in the State of Amazonas, Brazil. Melanthera discoidea plants with wilt symptoms were observed in three municipal districts in that State. The pathogen was isolated from vascular tissue and identified as Ralstonia solanacearum, race 1, biovars I and III. The inoculation of healthy $M$. discoidea plants reproduced the symptoms observed in the field, and the bacterium was reisolated. The bacterium strains isolated were also pathogenic to tomato (Lycopersicon esculentum), sweet pepper (Capsicum annuum), potato (Solanum tuberosum) and eggplant (Solanum melongena) and were not pathogenic to banana (Musa sp.). This is the first report of bacterial wilt in M. discoidea plants caused by $R$. solanacearum.
Melanthera discoidea Blake é uma planta herbácea com $1 \mathrm{~m}$ de altura e flores brancas, pertencente à família Asteraceae. A espécie é comum em áreas de floresta degradada de terra firme e em várzeas no Estado do Amazonas. Em hortas domésticas, essa espécie é encontrada, com freqüência, como uma planta invasora. Em um levantamento da ocorrência de murcha bacteriana em tomateiro (Lycopersicon esculenntum Mill.), realizado em 23 municípios desse Estado, no período de 1998 a 2000, foi observada a presença de plantas de $M$. discoidea com sintomas de murcha, nos municípios de Iranduba, Coari e Humaitá. Após resultado positivo no teste de exsudação bacteriana em água, a bactéria foi isolada a partir de fragmentos de caule. Em meio semi-seletivo contendo cloreto de 2, 3, 5 trifenil tetrazólium (Kelman, A. Phytopathology 44: 693-695, 1954), as colônias apresentaram crescimento fluido e coloração branco-creme com a área central vermelho-rosada. Todas as 17 estirpes obtidas de plantas diferentes e provenientes dos três municípios provocaram reação hipersensível em folhas de fumo (Nicotiana tabacum L.). Plantas de M. discoidea cultivadas em vasos contendo solo esterilizado foram inoculadas, após ferimento de raízes, pela deposição, no solo, de $6 \mathrm{ml} \mathrm{de}$ suspensão bacteriana na concentração de $1 \times 10^{8}$ células $/ \mathrm{ml}$. Uma semana após a inoculação foram observados sintomas de murcha e a bactéria foi reisolada.

Plantas de tomateiro cv. Santa Cruz, batata (Solanum tuberosum L.) cv. Monalisa, berinjela (Solanum melongena L.) cv. Embu e pimentão (Capsicum annuum L.) cv. Yolo Wonder foram inoculadas com as estirpes da bactéria isoladas de $M$. discoidea seguindo-se a mesma metodologia usada no teste de patogenicidade. Mudas de bananeira (Musa sp.) cv. Prata foram inoculadas injetando-se $1 \mathrm{ml}$ de suspensão bacteriana ( $1 \times 10^{8}$ células $\left./ \mathrm{ml}\right)$, na base do pseudocaule. Todas as espécies, com exceção da bananeira, apresentaram sintomas de murcha.

Obteve-se reação positiva nos testes de solubilidade em KOH 3\%, oxidase, redução de nitrato para nitrito, hidrólise do Tween e reação negativa nos testes de crescimento em $\mathrm{NaCl} 2 \%$, anaerobiose, desidrolase arginínica e hidrólise do amido. Todos os isolados obtidos nos municípios de Coari e Humaitá pertenceram ao biovar I (não acidificaram os meios contendo maltose, lactose, celobiose, manitol, dulcitol e sorbitol). Dos sete isolados provenientes de Manacapuru, cinco pertenceram ao biovar I e dois ao biovar III (acidificaram os meios contendo maltose, lactose, celobiose, manitol, dulcitol e sorbitol). Com base nesses resultados concluiu-se tratar de Ralstonia (Pseudomonas) solanacearum (sin. Burkholderia solanacearum) Smith, biovares I e III, raça 1 (Hayward, A.C. Annual Review of Phytopathology 29: 65, 1991). Este é o primeiro relato da ocorrência de murcha bacteriana em $M$. discoidea. Ralstonia solanacearum é nativa dos solos da Amazônia e, provavelmente, possui diversos hospedeiros ainda não identificados. Esses hospedeiros selvagens servem de reservatório de inóculo para o patógeno, permitindo a sua sobrevivência por longos períodos no solo e dificultando a sua eliminação em áreas cultivadas. A eliminação seletiva de hospedeiros naturais, em áreas infestadas, pode contribuir para um controle da população do patógeno em um programa de manejo integrado da murcha bacteriana. 